e ISSN-0976-7223 | Visit Us - www.researchjournal.co.in

DOI : 10.15740/HAS/IJAE/7.2/467-472

\title{
Study on thermal energy scenario for in selected dairy products
}

A.G. CHAUDHARI AND J.B. UPADHYAY

Received : 21.03.2014; Accepted : 30.09.2014

See end of the Paper for authors' affiliation

Correspondence to :

A.G. CHAUDHARI

Department of Dairy

Engineering, Anand Agricultural University,

ANAND (GUJARAT) INDIA

Email : ashokchaudhari005@gmail.

com
ABSTRACT : A case study on the thermal energy analysis was performed for selected dairy products at commercial dairy plant. The purpose of the analysis was to determine the thermal energy usage in the processing line. This will ultimately leads to ensure efficient process with his her productivity and to improve productivity. Engineering services in dairy plants are considered as the area where simple plant optimization measures can lead to substantial and almost immediate savings. In general dairy plant is considered as the heat and mass transfer industry where thermal energy is the main energy utilized for dairy processing. In dairy processing plant, steam was utilized in liquid milk processing, cream pasteurization, cheddar cheese, mozzarella cheese, paneer, ice cream, basundi and ghee processes were found as 1.46, 3.00, $46.66,87.21,81.71,8.83,88.72$, and $64.62 \mathrm{~kg}$ per $100 \mathrm{~kg}$ product, respectively and condensate losses were $7.25,7.96,6.97,7.14,7.25,6.06,9.52$, and 6.88 per cent, respectively of the total heat per $100 \mathrm{~kg}$ product processing.

GEY WORDS : Thermal energy, Dairy processing, Consumption, Steam, Industry, Pressure, Temperature

- HOW TO CITE THIS PAPER : Chaudhari, A.G. and Upadhyay, J.B. (2014). Study on thermal energy scenario for in selected dairy products. Internat. J. Agric. Engg., 7(2) : 467-472. 